Niniejsza publikacja jest dostępna na licencji Creative Commons. Uznanie autorstwa-Użycie niekomercyjne-Bez utworów zależnych 3.0 Polska. Pewne prawa zastrzė̇one na rzecz autora. Zezwala się na wykorzystanie publikacji zgodnie z licencja - pod warunkiem zachowania niniejszej informacji licencyjnej oraz wskazania autora jako właściciela praw do tekstu. Treść licencji jest dostępna na stronie: http://creativecommons.org/licenses/by-nc-nd/3.0/pl/

Lingwistyka Stosowana 23: 3/2017, 107-117

\author{
Joanna KIC-DRGAS
}

Uniwersytet im. Adama Mickiewicza w Poznaniu

\title{
Polityka językowa przedsiębiorstwa a planowanie kursu języka specjalistycznego na przykładzie branży informatycznej
}

\begin{abstract}
:
Language policies in companies from the IT sector and the planning of related LSP courses

The development of communication skills in foreign languages is increasingly considered to be a top priority in professional environments. Misunderstandings based on miscommunications in multilanguage corporations contribute to decreasing efficacy and, consequently, lowered productivity and diminished profits. Employers formulate their expectations of employees as early as during the recruitment process. They also do so in later stages of employees' careers within the company through different forms of workshops and courses encouraging the improvement of employees' language skills. The aim of the following paper is to analyse employers' expectations of employees' knowledge of foreign languages (expressed in job advertisements) and the consequences that follow for planning an LSP course for the IT sector. Finally, the conclusions and possibilities of application in the field of LSP teaching will be discussed.
\end{abstract}

\section{Wstęp}

Dążenia do unifikacji w zakresie opisu i ewaluacji znajomości języków obcych, których namacalnym rezultatem jest powstanie Europejskiego Systemu Opisu Kształcenia Językowego, miały za zadanie w dużym stopniu ułatwić i rozpowszechnić standardy dotyczące znajomości języków obcych. W kontekście dydaktyzacji tak się z pewnością stało, co można zaobserwować w szczególności na podstawie dostępnych materiałów dydaktycznych do nauczania języków obcych. W skali ogólnoeuropejskiej, a nawet światowej ujednolicenie zasad i kryteriów opisu znajomości języków obcych wpłynęło niewątpliwie na szybki rozwój i umocnienie tzw. polityki językowej. Ciekawym, acz stosunkowo słabo zbadanym obszarem wpływu i kształtowania się jednolitych standardów dotyczących znajomości języka obcego jest z pewnością obszar zawodowy i choć wydawać by się mogło, że właśnie ten obszar najbardziej skorzysta z ujednoliconych kryteriów dotyczących opisu i ewaluacji znajomości języków, to w rzeczywistości okazało się inaczej.

Niniejszy artykuł ma na celu przeanalizowanie oczekiwań pracodawców w wybranym sektorze zawodowym - branży IT na terenie Wielkopolski. W celu dokładnego zbadania problemu zostały postawione następujące pytania badawcze: 
- Jakie są kompetencje językowe oczekiwane od pracowników branży IT w zakresie znajomości języków obcych?

- Jakie są kompetencje pozajęzykowe oczekiwane od pracowników branży IT i czy mogą znaleźć aplikację w nauczaniu języków specjalistycznych?

- Jakie przełożenie na planowanie kursu języka specjalistycznego dla danej branży będą miały wyniki analizy ogłoszeń o pracę?

W pierwszej części artykułu zostaną poruszone następujące kwestie: komunikacja specjalistyczna w przedsiębiorstwie oraz specyfika branży informatycznej w Polsce i Wielkopolsce. Punktem ciężkości kolejnej sekcji będzie próba zbadania polityki językowej przedsiębiorstw w branży informatycznej, opierając się na zaproponowanym przez S. Vandermeeren (1998) modelu badania potrzeb językowych. W ostatniej części przedstawione zostaną wyniki przeprowadzonego badania wraz z wnioskami i praktycznymi propozycjami implikacji w zakresie dydaktyki języków specjalistycznych.

\section{Komunikacja w przedsiębiorstwie}

Komunikacja specjalistyczna w przedsiębiorstwie może mieć charakter wewnętrzny i zewnętrzny, co obrazuje poniższy schemat:

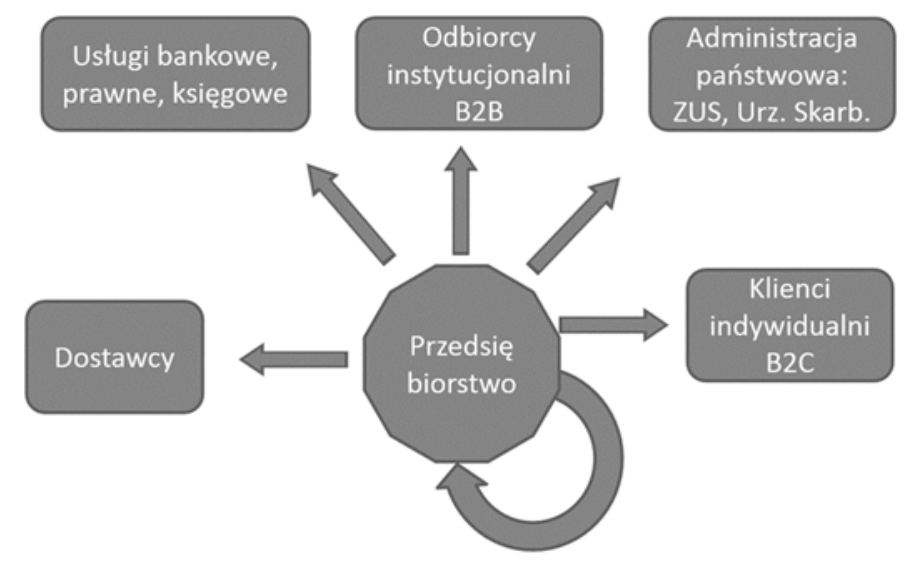

Rys.1. Schemat obrazujący komunikację wewnętrzna i zewnętrzna w przedsiębiorstwie.

Komunikacja zewnętrzna odbywa się między przedsiębiorstwem a podmiotami zewnętrznymi, takimi jak np. odbiorcy danych produktów, klienci, ale także administracja państwowa ZUS czy Urząd Skarbowy. Komunikacja w przedsiębiorstwie ma charakter specjalistyczny i można ją za S. Gruczą (2006) zdefiniować w następujący sposób:

Komunikacja specjalistyczna odbywa się między specjalistami reprezentującymi określoną dziedzinę, jednocześnie. Specjaliści komunikują się za pomocą tekstów specjalistycznych służących do wyrażenia ich wiedzy specjalistycznej (S. Grucza 2006: 210). 
J. Zając (2013: 36) proponuje wizualizację komunikacji specjalistycznej:

\section{Nadawca-specjalista $\longrightarrow$ Tekst specjalistyczny $\longrightarrow$ Odbiorca-specjalista}

Opierając się na powyższych rozważaniach S. Gruczy (2006) i J. Zając (2013) można wyodrębnić następujące determinanty komunikacji specjalistycznej:

- Uczestnicy - odbiorca, nadawca (eksperci/nie eksperci)

Warto podkreślić, że komunikacja specjalistyczna może przebiegać w opcji specjalista niespecjalista (np. urzędnik-petent) lub specjalista-specjalista. Temat doprecyzowuje J. Łompieś (2014: 57): „W odróżnieniu od komunikacji niespecjalistycznej uczestnikami komunikacji specjalistycznej są zwykle fachowcy i eksperci, przynajmniej po jednej z komunikujących się stron, co ma miejsce szczególnie wtedy, gdy jedna ze stron występuje w charakterze doradcy." W kontekście zawodowym to właśnie pracownicy i ich wiedza stanowią najważniejszy zasób danej organizacji (por. Z. Ciekanowski 2014: 136-138).

- Wiedza specjalistyczna

Wiedza uznana jest $\mathrm{w}$ środowisku zawodowym za kluczową wartość niematerialną, związaną nierozerwalnie $\mathrm{z}$ człowiekiem i elementem tak istotnych z punktu widzenia pracy i pracownika umiejętności. Pojęcie wiedzy definiuje w następujący sposób F. Grucza (1997): „Wiedza jest składnikiem umiejętności - każda umiejętność implikuje jakąś wiedzę, w szczególności pewną porcję wiedzy praktycznej. $Z$ drugiej strony wiedza może też istnieć samodzielnie - można wiedzieć, jak coś należałoby zrobić, ale nie potrafić tej czynności wykonać. Samodzielnie nie istnieje natomiast czysta sprawność.” (F. Grucza 1997: 13)

- Cel komunikacyjny

Kolejną istotną cechą komunikacji specjalistycznej jest jej cel, który H. P. Grice (1980:96) identyfikuje z walką o przetrwanie, w której nie chodzi o osiaggniecie kompromisu, lecz o osiągniecie dominacji na rynku lub wynegocjowanie lepszych warunków umowy.

- Język specjalistyczny/języki specjalistyczne

Języki specjalistyczne, które F. Grucza (2008) definiuje jako „pewne zbiory elementów językowych artykułujących pracę tych ludzi, opisujących przedmiot ich pracy, wyrażających ich stosunek do niego, nazywających wytwory (wyniki, produkty) ich pracy - to zbiory wyrażeń odzwierciedlających (reprezentujących) ich specjalistyczną wiedzę". (F. Grucza 2008: 14). Języki specjalistyczne zatem nie tylko służą komunikacji w kontekście specjalistycznym, ale także umożliwiają wyrażenie posiadanej wiedzy specjalistycznej w formie tekstów specjalistycznych. (S. Grucza 2013: 94) Jednocześnie ich powstanie i rozwój są niezaprzeczalnymi świadectwami postępującego rozwoju cywilizacyjnego (tamże: 7). 
- Tekst specjalistyczny

Posiadanie odpowiedniej wiedzy i znajomość języków specjalistycznych są warunkiem niezbędnym, od spełnienia którego zależy możliwość wytworzenia tekstów specjalistycznych. Stąd też teksty specjalistyczne można za S. Gruczą (2013: 85) zdefiniować w następujący sposób: „Teksty specjalistyczne to teksty wytworzone przez specjalistów w celu „wyrażenia” odpowiedniej specjalistycznej wiedzy".

Podsumowując, komunikacja w przedsiębiorstwie jest procesem złożonym, w którym obok odbiorcy i nadawcy pojawia się specjalistyczny cel komunikacyjny, a do jego realizacji niezbędna jest wiedza specjalistyczna wyrażona w formie tekstów specjalistycznych.

Przedstawione w tej części artykułu podstawy teoretyczne będą punktem wyjścia do dalszych rozważań dotyczących ich implikacji na grunt glottodydaktyki specjalistycznej. Punkt ciężkości został położony na język specjalistyczny branży informatycznej, stąd dalej przedstawiona zostanie sytuacja i znaczenie branży informatycznej w Polsce i Wielkopolsce (gdzie zostało przeprowadzone badanie opisane w części empirycznej).

\section{Sytuacja branży informatycznej w Polsce}

Branża informatyczna jest bardzo szybko rozwijającym się sektorem gospodarczym w Polsce. O dynamizmie rozwoju świadczą dane udostępnione przez GUS, według których liczba podmiotów działających w branży wzrosła w ciągu zaledwie czterech lat (2009-2013) z 40,2 tys. do 60,7 tysiąca. Według raportu Association of Business Service Leaders (2015) obszar IT obejmuje 33\% usług świadczonych na polskim rynku, stanowi tym samym największy obszar aktywności gospodarczej w Polsce. Fakt ten można tłumaczyć m.in. kompleksowym charakterem działania branży IT, która obejmuje następujące usługi: produkcję hardware, edukację, produkcję software, doradztwo, sprzedaż, przetwarzanie danych. Tak szeroki wachlarz działań przyczynia się także do rosnącego zatrudnienia w obszarze. W firmach świadczących usługi IT pracuje w Polsce ponad 140 tys. osób. Natomiast w dużych przedsiębiorstwach (zatrudniających co najmniej 200 osób) w usługach IT zatrudnionych jest 55 tys. pracowników, w tym około 18,7 tys. w firmach należących do krajowego kapitału. Dwie trzecie pracujących w dużych firmach oferujących usługi IT jest zatrudnionych $\mathrm{w}$ przedsiębiorstwach zagranicznych. $\mathrm{Z}$ powyższych informacji wynika, m.in. olbrzymie znaczenie znajomości języków obcych w branży informatycznej.

Czynniki wpływające na rozwój branży informatycznej w Polsce to:

- Czynniki zewnętrzne (globalizacja, dofinansowania, współpraca między przedsiębiorstwami, konkurencja, wzrost gospodarczy kraju, inflacja);

- Czynniki wewnętrzne (możliwości finansowe, aktualne ceny sprzętu i oprogramowania, konkurencja lokalna).

Okazuje się zatem, że dynamika branży wiąże się w dużym stopniu z jej interdyscyplinarnością i zależnością od rynków światowych, co z kolei znów pokazuje istotne znaczenie znajomości języków obcych w tej branży. 
W Wielkopolsce, gdzie zostało przeprowadzone opisane w dalszej części artykułu badanie empiryczne odnotowano, że specjalista IT jest wg Barometru Zawodów za rok 2016 zawodem deficytowym na poziomie powiatu, tzn. we wszystkich powiatach województwa wielkopolskiego odnotowano braki kadrowe w branży informatycznej.

\section{Potrzeby komunikacyjne w przedsiębiorstwie a autentyczne zastosowanie języka obcego}

S. Vandermeeren (1998) wskazuje na złożony charakter komunikacji w przedsiębiorstwie i na następujące czynniki, które należy uwzględnić, przy jej badaniu, a mianowicie:

- Potrzeby językowe (Sprachbedarf) - oznaczające zgłaszane przez pracodawcę zapotrzebowanie na określone umiejętności językowe, najczęściej pierwszą informacją dotycząca oczekiwań językowych pracodawcy są sformułowane przez niego ogłoszenia o pracę, w których pojawiają się wymogi dotyczące pracowników. Jednocześnie warto wskazać na kompleksowy charakter pojęcia. Według A. Verdoodt i A. Sente (1983: 265) potrzeby językowe to zarówno niezbędna znajomość języka, aby wykonać zadania na danym stanowisku, ale także brakujące umiejętności językowe: "For us the term 'language needs' consists of two relevant dimensions: 1. a language that is necessary; 2. a language knowledge that is lacking";

- Użycie języka (Sprachgebrauch) - drugim czynnikiem na który wskazuje S. Vandermeeren jest użycie języka, które autorka rozróżnia od zapotrzebowania w następujący sposób:

„Der tatsächliche Fremdsprachengebrauch eines Unternehmens kann nur dann als mit seinem Fremdsprachenbedarf identisch betrachtet werden, wenn kein Mehrbedarf an Fremdsprachen vorausgesetzt wird" (S. Vandermeeren 2016: 293).

Zatem użycie języka jest równe autentycznie zgłaszanym potrzebom, jeśli znajomość języka osób zatrudnionych w danej instytucji pokrywa wszystkie potrzeby komunikacyjne powstałe $\mathrm{w}$ danym przedsiębiorstwie. Zaprezentowane przez S. Vandrmeeren $(1998,2016)$ oraz S. Vandrmeeren i A. Hofman (2015) podejście było podstawą przeprowadzonego w części empirycznej badania.

Zarówno użycie języka w przedsiębiorstwie, jak i potrzeby językowe konstytuują politykę językową przedsiębiorstwa, a więc, najogólniej przyjmując, zbiór reguł i zasad dotyczących używania języka lub języków w obrębie danej jednostki organizacyjnej oraz $\mathrm{w}$ kontaktach $\mathrm{z}$ podmiotami zewnętrznymi. W ramach polityki językowej przedsiębiorstwa ustalany jest status poszczególnych języków w obiegu firmowym, ale także metody wspierania nauczania poszczególnych języków.

\section{Opis badania}

W ramach badania przeanalizowano 80 ogłoszeń o pracę w branży informatycznej dotyczących stanowisk z branży IT na terenie Wielkopolski. W badaniu zostały 
zadane następujące pytania badawcze:

- Znajomość jakich języków jest wymagana/oczekiwana przez pracodawcę?

- Znajomość języka na jakim poziomie?

- Jakie umiejętności dodatkowe są wymagane od potencjalnych pracowników?

- Jakie elementy polityki językowej przedsiębiorstwa można odnaleźć w ogłoszeniach?

Analizowane ogłoszenia zbierane były zarówno z gazet, wydania Głosu Wielkopolskiego, Gazety Wyborczej, jak i stron internetowych z ofertami pracy: pracuj.pl, oraz praca.pl, w okresie od 01.01 do 31.03.2017 roku.

\section{Wyniki badania}

- Wymagania dotyczące znajomości języków obcych

W poniższej tabelce zaprezentowane zostały informacje dotyczące wymagań dotyczących znajomości języków obcych na wielkopolskim rynku informatycznym.

\begin{tabular}{|l|l|l|}
\hline Opis & Liczba ogłoszeń & $\begin{array}{l}\text { Dodatkowe } \\
\text { informacje }\end{array}$ \\
\hline $\begin{array}{l}\text { Brak informacji o } \\
\text { znajomości języka } \\
\text { obcego }\end{array}$ & 7 & \\
\hline $\begin{array}{l}\text { Znajomość tylko } \\
\text { języka angielskie- } \\
\text { go }\end{array}$ & 63 & $\begin{array}{l}12 \\
\text { sformułowano w } \\
\text { języku angielskim }\end{array}$ \\
\hline $\begin{array}{l}\text { Znajomość tylko } \\
\text { języka niemieckie- } \\
\text { go }\end{array}$ & 6 & \\
\hline $\begin{array}{l}\text { Znajomość innych } \\
\text { jezzyków obcych }\end{array}$ & brak & \\
\hline $\begin{array}{l}\text { Znajomość dwóch } \\
\text { języków obcych }\end{array}$ & $\begin{array}{l}\text { 4 ogłoszenia } \\
\text { j. angielski jako } \\
\text { główny } \\
\text { i j. niemiecki jako } \\
\text { dodatkowy) }\end{array}$ & \\
\hline
\end{tabular}

Tabela 1. Rozkład oczekiwań językowych $w$ analizowanych ogłoszeniach o pracę.

Z powyższych danych można wywnioskować, że znajomość języka angielskiego jest najczęściej (w 67 ogłoszeniach) oczekiwaną kompetencją wśród pracodawców w branży IT. Interesujący jest fakt, że w 12 przypadkach ogłoszenie zostało sformułowane $\mathrm{w}$ języku angielskim, aby prawdopodobnie już na samym początku procesu rekrutacyjnego zweryfikować znajomość języka obcego wśród osób szukających pracy na podstawie tekstu zamieszczonego w treści ogłoszenia. Drugim językiem pojawiającym się w ogłoszeniach jest język niemiecki, przy czym w sześciu przypadkach jest to język główny. W czterech ogłoszeniach pracodawcy zaznaczyli w swoich oczekiwaniach wymóg znajomości dwóch języków obcych (języka angiel- 
skiego i niemieckiego). W siedmiu ogłoszeniach nie zostały ujęte informacje w zakresie znajomości języków obcych.

- Poziom znajomości języka obcego

Mimo bardzo precyzyjnie sformułowanych ram określających znajomość języków obcych w różnych obszarach zawartych w Europejskim Systemie Opisu Kształcenia Językowego pracodawcy nie do końca przejęli zaproponowaną systematykę w określaniu oczekiwań wobec potencjalnych pracowników. Poniżej kilka sformułowań wyekstrahowanych z analizowanych ogłoszeń:

- Excellent oral and written communication skills in English;

- Znajomość języka angielskiego na poziomie średniozaawansowanym;

- Język angielski - komunikatywny w mowie i piśmie;

- Przynajmniej podstawowa znajomość języka niemieckiego;

- Dobra lub komunikatywna znajomość języka angielskiego (min. B1);

- Język angielski na poziomie zaawansowanym (C1);

- Znajomość języka angielskiego na poziomie swobodnej komunikacji;

- Proficient in English (written/spoken);

- Knowledge of German would be an asset.

Duże wątpliwości budzi na przykład sformułowanie excellent skills, czy jest to już poziom C1, czy C2 określany przez Europejski System Opisu Kształcenia Językowego. Kolejną niejasną kwestią jest to, czym jest poziom swobodnej komunikacji $w$ języku. Czy rzeczywiście w pracy w branży IT niezbędna jest znajomość języka na poziomie Proficiency (określana w ESOKJ jako znajomość na poziomie rodzimego użytkownika danego języka)?

$\mathrm{Z}$ pewnością dużą pomocą w odpowiedzi na te pytania będzie dalsza część badania (zaprezentowana w innej publikacji) obejmującego pogłębione wywiady z pracodawcami na temat prowadzonej przez nich polityki językowej, niemniej na ten moment można stwierdzić dużą niejednorodność i niekonsekwencję w sformułowaniach dotyczących wymagań językowych stawianych przyszłym pracownikom w branży IT.

W ogłoszeniach pojawiają się konkretne informacje dotyczące znajomości elementów języka specjalistycznego, poniżej kilka przykładów:

- znajomość języka angielskiego w stopniu umożliwiającym pracę $\mathrm{z}$ dokumentacją techniczną;

- znajomość języka angielskiego w stopniu pozwalającym na czytanie dokumentacji;

- wysyłanie zaproszeń, wprowadzanie wyników do bazy danych, planowanie rozmów rekrutacyjnych;

- $\quad$ stały kontakt telefoniczny oraz mailowy z kandydatami;

- excel proficiency and ideally experience in the creation of reports;

- strong written and oral communication;

- doświadczenie w tworzeniu i zarządzaniu dokumentacją techniczną;

- skills to effectively present information to various groups of recipients. 
W 45 spośród analizowanych ogłoszeń znalazły się informacje wskazujące na fakt, że pracodawcy poszukują potencjalnie pracowników wykazujących się znajomością języka specjalistycznego. W 10 ogłoszeniach pracodawcy wskazywali na potrzebę znajomości języka technicznego (pracy z dokumentacją techniczną). Interesującym jest fakt, że w 26 ogłoszeniach pracodawcy wskazali na oczekiwania dotyczące umiejętności pisania tekstów specjalistycznych w języku obcym (raportów, dokumentów technicznych, maili oficjalnych).

Dodatkowo w ogłoszeniach pojawiły się oczekiwania dotyczące kompetencji pozajęzykowych, niemniej te kompetencje mogą znaleźć się w programie kursu języka specjalistycznego:

- ability to work in high pressure;

- extensive interpersonal skills;

- umiejętnie wyznaczać priorytety;

- umiejętność samodzielnego rozwiązywania podstawowych problemów na podstawie określonych zasad i procedur;

- umiejętności analityczne stosowane do rozwiązywania skomplikowanych problemów;

- wysoko rozwinięte zdolności organizacyjne, komunikacyjne i interpersonalne.

Z przytoczonych przykładów można wywnioskować, że olbrzymie znaczenie dla pracodawców mają umiejętności określane jako tzw. miękkie, określające płynną współpracę w zespole specjalistów.

\section{Wnioski dla planowania kursu języka specjalistycznego}

Na tym etapie rozważań można sformułować następujące wnioski istotne z punktu widzenia glottodydaktyki specjalistycznej:

- Mimo iż język angielski jest pierwszym językiem obcym w komunikacji w branży IT, to jednak w wielu przypadkach to język niemiecki jest dodatkowym atutem na rynku pracy

- Na zajęciach z języka specjalistycznego powinna być obok komunikacji ustnej ćwiczona komunikacja pisemna, która, jak wynika z oczekiwań umieszczonych $\mathrm{w}$ przeanalizowanych ogłoszeniach o pracę, jest bardzo istotna dla przyszłych pracodawców;

- Niezbędna jest także pogłębiona praca (zarówno perceptywna, jak i receptywna) z tekstem specjalistycznym, który jest nie tylko podstawowym źró-

1 „,...) poznańskich centrach usług w III i IV kw. 2016 r. dotyczyło kandydatów komunikujących się w języku niemieckim. Biorąc pod uwagę trendy rozwojowe zarówno dojrzałych, jak i nowo powstałych poznańskich centrów usług oraz istotny udział firm niemieckich wśród wspomnianych podmiotów, można przypuszczać, że specjaliści posługujący się tym językiem będą w nadchodzących latach należeć do najbardziej poszukiwanych.” Związek Liderów Sektora Usług Biznesowych (ABSL) 2017, http://absl.pl/wpcontent/uploads/2016/10/raport_it_2015_PLv151210.pdf [Pobrano 16.05.2017]. 
dłem wiedzy specjalistycznej w przedsiębiorstwie, ale także wiedzy na temat funkcjonowania terminów specjalistycznych w danym kontekście;

- Ćwiczenia planowane w oparciu o korpusy autentycznych tekstów (autentyczność przykładów), wzmacniające także motywację uczących się i praktyczny charakter zajęć;

- Rozwijanie umiejętności rozwiązywania problemów/ustalania priorytetów/negocjacji, np. za pomocą case study.

\section{Podsumowanie i postulaty}

Nauczanie języka specjalistycznego na potrzeby rynku pracy powinno mieć przede wszystkim charakter praktyczny, co wynika ze specyfiki nauczanej grupy i stawianych celów. W podjętych rozważaniach grupę docelową mogą stanowić studenci przygotowujący się do podjęcia pracy w branży IT (studenci informatyki, ale także studenci filologii, którzy coraz częściej znajdują zatrudnienie w centrach usług wspólnych) lub osoby czynne na rynku pracy, które planują zmianę pracy, bądź także osoby, które są już czynne zawodowo w danej branży i chcą lepiej spełniać oczekiwania pracodawcy, a poprzez to efektywniej funkcjonować na rynku pracy.

$\mathrm{Na}$ podstawie analizy zebranych ogłoszeń stwierdzono wyraźne zapotrzebowanie pracodawców dotyczące kompetencji komunikacyjnych ustnych, ale także pisemnych, co w dużym stopniu przekłada się na kompozycję zajęć specjalistycznych i włączenie do programu zajęć ćwiczenia form pisemnych, takich jak mail, raport czy instrukcja, stosowanych w obiegu komunikacyjnym w przedsiębiorstwie. Obok umiejętności językowych pracodawcy coraz częściej przywiązują wagę do ćwiczenia umiejętności określanych jako tzw. miękkie, tj.: analiza danych, rozwiązywanie problemów, prezentowanie określonych rozwiązań, umiejętność argumentowania, negocjowania etc. Te umiejętności mogą być także ćwiczone w trakcie kursu specjalistycznego w formie różnego typu zadań typu case study (studium przypadku), role play (wcielania się w role) czy pracy z autentycznymi danymi.

Autentyzm to druga ważna cecha nauczania języka specjalistycznego, bardzo mocno powiązana z pragmatyzmem. Nauczanie języka specjalistycznego przyjmuje za cel przygotowanie do działań językowych mających miejsce w autentycznej przestrzeni zawodowej, powinno zatem być jak najbardziej zbliżone do rzeczywistych sytuacji komunikacji językowej, aby osiągnąć jak największą skuteczność. Ta autentyczność może być zapewniona poprzez pracę na autentycznych materiałach i tekstach specjalistycznych.

Kolejnym postulatem, który nasuwa się po przeanalizowaniu wyników przeprowadzonej analizy jest współpraca uczelni (w szczególności jednostek odpowiedzialnych za nauczanie języków obcych) z sektorem zawodowym. Jeśli w przypadku różnego typu przedmiotów o charakterze zawodowym taka współpraca funkcjonuje już od dawna w formie różnego typu spotkań z praktykami, praktyk, wykładów, to w kontekście nauczania języka specjalistycznego jest często bardzo ograniczona, a przecież podstawowym celem nauczania języka specjalistycznego jest przygotowanie do funkcjonowania w autentycznych warunkach komunikacyjnych funkcjonujących w danej branży. Nikt zatem nie będzie w stanie lepiej opisać tych warunków 
niż sami praktycy. Zasadnym zdaje się więc organizowanie wyjść do zakładów pracy połączonych $\mathrm{z}$ prezentacjami $\mathrm{w}$ językach obcych lub wspólne projekty $\mathrm{z}$ ekspertami z punktem ciężkości zorientowanym na kształcenie językowe, jednym słowem przybliżenie komunikacji w środowisku zawodowym.

Przedstawiony $\mathrm{w}$ artykule materiał stanowi zaledwie fragment badania, które z pewnością zasługuje na poszerzenie i dalsze analizy. Co więcej, omówiony zakres tematyczny jest w Polsce stosunkowo mało zdiagnozowany ${ }^{2}$, a w związku $z$ rozwijającym się popytem na usługi edukacyjne w obszarze nauczania języków specjalistycznych jego pogłębiona analiza jest bardzo potrzebna.

\section{Bibliografia}

Alnajjar, J. (2013), Communication in global corporations. Successful Project Management via Email. Frankfurt/Main: Peter Lang.

Association of Business Service Leaders (2015), Rynek usług w Polsce, (URL http://absl.pl/wp-content/uploads/2016/10/raport_it_2015_PLv151210.pdf). [Pobrano 16.05.2017].

Barometr zawodów (2016), Raport podsumowujacy badanie $w$ województwie wielkopolskim. Kraków: Wojewódzki Urząd Pracy w Krakowie.

Ciekanowski, Z. (2014), Kapital ludzki najistotniejszym elementem $w$ organizacji, (w:) ,Zeszyty Naukowe Uniwersytetu Przyrodniczo-Humanistycznego w Siedlcach" 101, 135-148.

Grice, H. P. (1980), Logika i konwersacja, (w:) B. Stanosz (red.), Język w świetle nauki. Warszawa, 91-114.

Grucza, F. (1997), Języki ludzkie a wyrażenia językowe, wiedza a informacja, mózg a umyst ludzki, (w:) F. Grucza/ M. Dakowska (red.), Podejścia kognitywne w lingwistyce, translatoryce i glottodydaktyce. Warszawa, 7-21.

Grucza, F. (2008), Języki specjalistyczne - indykatory i/lub determinanty rozwoju cywilizacyjnego, (w:) J. Lukszyn (red.), Podstawy technolingwistyki I. Warszawa, 5-23.

Grucza, S. (2006), Komunikacja specjalistyczna a idiokontekst specjalistyczny i konsytuacja specjalistyczna, (w:) A. Wołodźko-Butkiewicz/ W. Zmarzer (red.), Studia Rossica XVIII. Glottodydaktyka i jej konteksty interkulturowe, Warszawa, 209-223.

Grucza, S. (2008), Lingwistyka języków specjalistycznych. Warszawa.

Grucza, S. (2013), Od lingwistyki tekstu do lingwistyki tekstu specjalistycznego. Warszawa.

Grucza, S./ J. Alnajjar/ P. Bąk (2014), Polnisch-deutsche Unternehmenskommunikation. Frankfurt/Main.

Łompieś, J.B. (2014), Raport spótki giełdowej. Studium pragmalingwistyczne. Warszawa.

${ }^{2}$ Warto na tym miejscu wspomnieć o badaniach prowadzonych przez S. Gruczę, J. Alnajjar i P. Bąka (2014) oraz J. Alnajjar (2013) i na temat komunikacji w przedsiębiorstwach. 
Vandermeeren, S. (1998), Fremdsprachen in europäischen Unternehmen. Untersuchungen zu Bestand und Bedarf im Geschäftsalltag mit Empfehlungen für Sprachenpolitik und Sprachunterricht. Waldsteinberg.

Vandermeeren, S. (2016), Dänisch oder Deutsch? Die Ergebnisse einer Fragebogenaktion unter norddeutschen und dänischen Manager_innen zum Sprachgebrauch und -bedarf ihrer Unternehmen. (w:) „Linguistik Online“ 79(5), 291232. (URL: http://dx.doi.org/10.13092/lo.79.3347). [Pobrano 14.04.2017].

Vandermeeren, S./ A. Hofman (2015), Wie lassen sich Stereotype mit Kulturdimensionen verknüpfen? Eine empirische Untersuchung in Deutschland und Dänemark, (w:) J. Andrzejewska (red.), Das Fremde in interkulturellen Untersuchungen. Erfurt, 127-146.

Verdoodt, A./ A. Sente (1983), Interest shown by secondary school pupils in modern languages and adult language needs in Belgium, (w:) M. Oud-de Glas/ T.van Els (red.), Research into foreign language needs,Augsburg: Universität Augsburg, 263-283.

Zając, J. (2013), Specjalistyczna komunikacja multikulturowa i multilingwalna w korporacjach globalnych. Warszawa.

Związek Liderów Sektora Usług Biznesowych (ABSL) 2017, http://absl.pl/wpcontent/uploads/2016/10/raport_it_2015_PLv151210.pdf [Pobrano 16.05.2017]. 